\title{
Inter-ramet Photosynthate Translocation in Buffalograss under Differential Water Deficit Stress
}

\author{
Yongqiang Qian \\ Research Institute of Forestry, Chinese Academy of Forestry, Key Laboratory of Tree Breeding and \\ Cultivation, State Forestry Administration, Beijing 100091 China
}

Deying Li

Department of Plant Sciences, North Dakota State University, Fargo, ND 58108

Lei Han and Zhenyuan Sun ${ }^{1}$

Research Institute of Forestry, Chinese Academy of Forestry, Key Laboratory of Tree Breeding and Cultivation, State Forestry Administration, Beijing 100091 China

\begin{abstract}
AdDitional INDEX wORDs. Buchloe dactyloides, clonal, physiological integration, turfgrass, ecology
ABstract. Understanding the effect of photosynthate translocation on the shoot density of buffalograss (Buchloe dactyloides) is very important to improve its turf quality. The objective of this study was to examine the effects of water stress on water transport patterns, endogenous hormone distribution and allocation, and photosynthate allocation for connected buffalograss ramets. Clones from a single parent plant of 'Texoka' buffalograss were used to generate three-ramet units. Ramets are members of a clone that are not independent from the parent plant. Each water stress treatment had one of the three ramets cultured in half-strength Hoagland solution with $30 \%$ of polyethylene glycol (PEG) of $-1.2 \mathrm{MPa} \psi_{\mathrm{s}}$, while the other two ramets were kept in half-strength Hoagland solution with $\psi_{\mathrm{s}}$ of $-0.05 \mathrm{MPa}$. Results indicated that inter-ramet water integration happened when one of the connected ramets was under water stress. Transzeatin riboside content decreased in roots treated with PEG. Abscisic acid content increased in the roots of all treatments compared with the control. Water stress caused a reduction of indole-3-acetic acid content in shoots and roots, especially the ramet stressed. Gibberellic acid content in shoots and roots of all treatments increased compared with the control. Within the control, young ramets were sinks of photosynthate, but translocation toward older ramets was detected using ${ }^{14} \mathrm{CO}_{2}$ label when the older ramet was under stress. Xylem, phloem, and parenchyma cells were probably involved in the physiological integration of these responses. Fates of connected clonal ramets of buffalograss were interrelated and the agronomic significance of this result should be evaluated further.
\end{abstract}

Buffalograss is native to the Great Plains of North America (Huff and Wu, 1987). This species is widely used as a lowmaintenance turfgrass in parks, cemeteries, and rights of way due to its excellent cold, heat, and drought tolerance (Beard, 1985). Buffalograss is increasingly used on golf course fairways and other sports fields in arid and semiarid regions where water shortage is becoming an important concern (Frank et al., 2004; Pozarnsky, 1983). However, one of the weaknesses of buffalograss for use in golf fairways is poor ball-supporting ability due to low shoot density. Improving the traits related to shoot density has been proposed as one of the goals in buffalograss breeding programs (Johnson et al., 2000; Taliaferro and McMaugh, 1993). Buffalograss is considered a "guerilla"-type clonal species (Lovett Doust, 1981), meaning it can spread extensively. The opposite are "phalanx"-type plants [short nodes and compact growth (Lovett Doust, 1981)], which have higher potential for shoot density because of the intensive growth habit. Limited information is available on shoot density affected by the growth type, "guerilla" type versus "phalanx" type, although research has been conducted on the effects of nitrogen and mowing height (Frank et al., 2004). No research has yet been

Received for publication 26 Mar. 2010. Accepted for publication 2 June 2010. This research was supported by the Hi-Tech Research and Development (863) Program of China (2007AA100105 and 2006AA100109) and by the Special Natural Science Fund for Non-for-profit National Institutions (RIF2010-11)

${ }^{1}$ Corresponding author. E-mail: sunzy@caf.ac.cn. conducted to understand the effect of nutrient and carbohydrate translocation on the shoot density of buffalograss.

Reproduction and population density are often discussed in relation to population biology and ecology of clonal plants. Semiautonomous young ramets may import nutrients, water, hormones, etc., from the parent until they are established, and thereafter they may be independent of parental support (Pitelka and Ashmun, 1985). In ecological research, members of a clone are considered ramets before they become independent from the parent plant for study of photosynthate partition (Alpert, 1991). Another important characteristic of clonal plants is physiological integration, which is defined as a process of redistribution of assimilated resources among the interconnected ramets according to source-sink relationships (Forde, 1966; Kaitaniemi and Honkanen, 1996; Marshall, 1990). Physiological integration is an important means by which clonal plants adapt to heterogeneous environmental conditions (Kroon et al., 1996; Marshall, 1990). Because buffalograss has a "guerilla"-type growth habit, it may differentially exploit the environment, selecting favorable and avoiding unfavorable sites (Jackson, 1979). As a stoloniferous clonal species, buffalograss clones are often connected for an extended period of time after establishment.

Resource sharing in clonal plants is reflected in the ability of perennial grasses to change phenotypes in response to fluctuating environments and stresses (Bradshaw, 1965). For instance, the specialization of certain ramets in photosynthesis and nutrient-uptaking functions may be enhanced when essential nutrients and light are heterogeneously distributed (Stuefer 
et al., 1994). The consideration of phenotypic changes in turfgrass breeding was discussed by Casler and Duncan (2003) and Bradshaw (1965). An internal gradient was established when connected ramets were exposed to different nutrient availability (Marshall, 1990), and such a gradient may be the driving force for the nutrient redistribution (Marshall and Price, 1999). Water was transported from parent ramets to offspring ramets along the water potential gradient in Fragaria chiloensis (Alpert and Mooney, 1986). Photosynthate also was translocated among connected ramets in many grass species (Nyahoza et al., 1974; St. Pierre and Wright, 1972). However, the mechanisms of physiological integration in grasses are not well understood (Hellström et al., 2006).

Huang (1999) reported that buffalograss performed better than zoysiagrass (Zoysia japonica) under localized soil drying and attributed the difference to the more extensive root system in buffalograss. Qian et al. (2009) reported that buffalograss shoot number displayed water integration when connected ramets were grown in media with different soil water contents. The same authors also reported inter-ramet translocation of lipid peroxidation, antioxidants, and proline (Qian et al., 2009). High uniformity is a major quality component of turf. One of the purposes of topdressing and applying wetting agents, among many other turfgrass management practices, is to correct the heterogeneous conditions in the root zone media and to create uniform turf (Karnok and Tucker, 2001; Minner et al., 1997). This integration appears to deal with soil variability to provide more uniform growth in buffalograss - a highly desirable trait. Understanding this process may also help to make precise cultural practices and improve turf uniformity.

The role of plant hormones in response to drought stress has been discussed for endogenous (Abreu and Munne-Bosch, 2008) and exogenous (Liu and Huang, 2002; Zhang and Schmidt, 1999) sources. Abscisic acid was found to play a role in water stress-induced antioxidants (Jiang and Zhang, 2002) and morphological responses (Zhang and Davies, 1989). Increased contents of zeatin riboside (ZR) in shoot and root alleviated the heat stress in creeping bentgrass (Agrostis palustris) (Liu and Huang, 2002). Gibberellic acid treatment delayed senescence in bermudagrass (Cynodon dactylon) caused by chilling (DiPaola et al., 1981). Research also indicated that hormone allocation was modified in the process of resource sharing in clonal plants of F. chiloensis (Alpert et al., 2002).

The primary objective of this study was to assess the effects of differential water stress on water transport and photosynthate translocation and distribution. A secondary objective was to examine if endogenous hormone translocation and distribution display coordinated changes under differential water stress in buffalograss.

\section{Materials and Methods}

Plant materials used in this study were clones from a single parent plant of 'Texoka' buffalograss vegetatively propagated in a greenhouse (Chinese Forestry Institute, Beijing, China) with temperatures at $25 \pm 2{ }^{\circ} \mathrm{C}$ and relative humidity at $50 \% \pm$ $10 \%$, and supplemental light provided by metal halide lamps on a 16-h photoperiod. The connected ramets were produced by generating roots and shoots at the nodes of buffalograss stolons. To summarize, each node of a stolon with four to five nodes was placed in an individual plastic cup $(10 \times 10 \times 10 \mathrm{~cm})$ and was covered with a mixture of sand and peat in equal volumes on 15
June 2007. The rooting medium was fertilized at the beginning of the experiment with a $12 \mathrm{~N}-5.3 \mathrm{P}-10 \mathrm{~K}$ water-soluble fertilizer at $50 \mathrm{~kg} \cdot \mathrm{ha}^{-1} \mathrm{~N}$ and was kept moist by frequent watering under a mist spray system. On 5 July 2007, 3 weeks after the initiation of tiller induction, sections containing three connected ramets were harvested by cutting them off the stolons and uniform sections were selected for the experiments. The sections did not include the unrooted newest nodes at the tip of stolons, which were cut off at the harvest. In this study, a ramet is defined as a tiller with developed shoot and roots at one node. The youngest, second, and oldest ramets were denoted as $R_{1}$, $\mathrm{R}_{2}$, and $\mathrm{R}_{3}$, respectively. The roots of connected ramets were rinsed free of growth media with distilled water and each ramet was cultured in a separate glass flask with $200 \mathrm{~mL}$ of halfstrength Hoagland solution (Hothem et al., 2003) $\left(\psi_{\mathrm{o}} \approx-0.05\right.$ $\mathrm{MPa}, \mathrm{pH}=5.8$ ) for $6 \mathrm{~d}$ before the initiation of treatments in different experiments (Fig. 1). Osmotic potential of Hoagland solution was measured using a dew point potential meter (WP4; Decagon Device, Pullman, WA). The solution was changed daily and air was pumped into the hydroponic solution through pressure-regulating valves and PVC tubes with a porous stone cap at the end of each tube in the containers.

Three experiments were included in this study and all followed a similar general setup as follows. The first group of ramets had $\mathrm{R}_{3}$ cultured in half strength Hoagland solution with $30 \%$ of PEG-8000 (previously named PEG-6000; SigmaAldrich, St. Louis) $\left(\psi_{\mathrm{o}} \approx-1.2 \mathrm{MPa}\right)$, while $\mathrm{R}_{1}$ and $\mathrm{R}_{2}$ were kept in half strength Hoagland solution only, and was denoted as $R_{3}{ }^{P} R_{2} R_{1}$. The second group of ramets had $R_{2}$ cultured in half strength Hoagland solution with $30 \%$ of PEG-8000, while $\mathrm{R}_{1}$ and $\mathrm{R}_{3}$ were kept in half strength Hoagland solution only, and was denoted as $R_{3} R_{2}{ }^{P} R_{1}$. The third group of ramets had $R_{1}$ cultured in half strength Hoagland solution with $30 \%$ of PEG8000 , while $R_{2}$ and $R_{3}$ were kept in half strength Hoagland solution only, and was denoted as $R_{3} R_{2} R_{1}{ }^{P}$. The fourth group of ramets had all three ramets cultured in half strength Hoagland solution and served as a control, $\mathrm{R}_{3} \mathrm{R}_{2} \mathrm{R}_{1}$. Polyethylene glycol has been used in a number of studies to decrease the $\psi_{\mathrm{S}}$ of solutions (Jia et al., 2001; Jiang and Zhang, 2002; Nayyar, 2003). These ramet groups were maintained in a growth chamber with

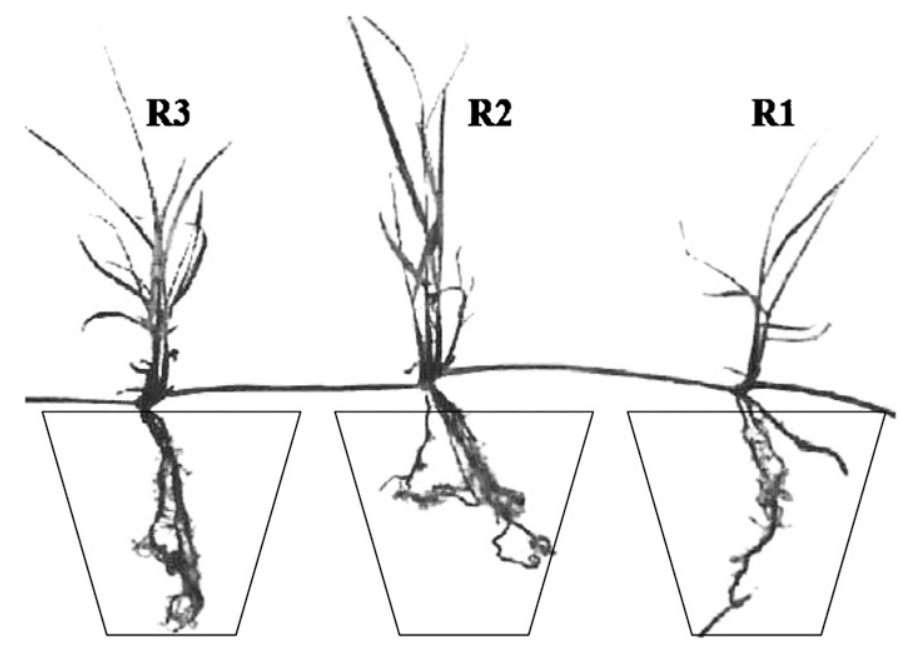

Fig. 1. Diagram showing the interconnected ramets of 'Texoka' buffalograss grown in separate containers, where $\mathrm{R}_{3}, \mathrm{R}_{2}$, and $\mathrm{R}_{1}$ represent the oldest, second, and youngest ramet, respectively. 
a 10 -h photoperiod, light intensity of $500-600 \mu \mathrm{mol} \cdot \mathrm{m}^{-2} \cdot \mathrm{s}^{-1}$, temperature at 24 to $28{ }^{\circ} \mathrm{C}$, and relative humidity at $45 \%$ to $60 \%$.

Experiment 1 was intended to monitor the direction of water movement in the connected ramets when one of them was under water stress from the addition of PEG-8000. Acid fuchsin dye (EMD Chemicals, Gibbstown, NJ) has been used to trace xylemmediated water transport in many species (Baum et al., 2000; Warren et al., 2008), where water transport followed the route of dye tracer. In this study, acid fuchsin dye was added to the culture solutions, one ramet at a time within each group, at a concentration of $0.25 \mathrm{~g} \cdot \mathrm{L}^{-1}$. A superscript $\mathrm{D}$ was added to $\mathrm{R}_{3} \mathrm{R}_{2} \mathrm{R}_{1}$ to denote dye addition to its culture solution. The acid fuchsin tracing treatments were arranged in a randomized complete block design with three replications. Each treatment unit contained three plants. The roots, leaves, and internodes of all ramets were visually observed $4 \mathrm{~h}$ after the dye was added and the organs were recorded as positive if red color was observed.

The purpose of Expt. 2 was to assess hormonal distribution in shoots and roots of different ramets affected by water deficit stress in one ramet. In this experiment, the treatments also were arranged in a randomized complete block design with three replications. Each treatment unit contained 10 plants. The leaves, roots, and internodes of $R_{1}, R_{2}$, and $R_{3}$ were harvested $4 \mathrm{~h}$ after the PEG treatment was applied. The samples were ground with an ice-cold mortar and a pestle in $6 \mathrm{~mL}$ of ice-cooled $80 \%$ methanol $(\mathrm{v} / \mathrm{v})$ containing $1 \mathrm{mmol} \cdot \mathrm{L}^{-1}$ butylated hydroxytoluene (BHT) to prevent oxidation and incubated overnight at $4{ }^{\circ} \mathrm{C}$ before centrifugation at $5000 g_{n}$ for $15 \mathrm{~min}$ at $4{ }^{\circ} \mathrm{C}$. After removing the supernatant, the residues were suspended with icecooled extraction solution in darkness for $4 \mathrm{~h}$ and centrifuged again at $4{ }^{\circ} \mathrm{C}$. The two supernatants were combined and passed through a Chromosep C18 column (Waters, Milford, MA). The efflux was dried in a freeze dryer (Labconco, London) and was then dissolved in $2 \mathrm{~mL}$ of phosphate-buffered solution (PBS) containing $0.1 \%$ (v/v) polysorbate 20 (Tween-20; Fisher Scientific, Pittsburgh) and $0.1 \%$ gelatin (Fisher Scientific; $\mathrm{pH} 7.5$ ). The solution was used for determination of concentrations of indole3-acetic acid (IAA), gibberellic acid (GAs), tans-ZR, and abscisic acid (ABA) by enzyme-linked immunoabsorbent assay (ELISA) following the methods described by Yang et al. (2001). The mouse monoclonal antigens and antibodies against ZR, IAA, GAs, and ABA used in ELISA were produced at the Phytohormones Research Institute (China Agricultural University, Beijing, China). IgG-horseradish peroxidase was purchased from Sigma-Aldrich. The absorbance was measured at $490 \mathrm{~nm}$ using an ELISA recorder (model DG-3022A; Huadong Electron Tube Factory, Shanghai, China). Calculations for the concentration of IAA, GAs, ZR, and ABA were performed following Weiler et al. (1981). The recovery of each hormone was monitored by adding a known amount of standard hormone to a split extract. All recoveries were over $90 \%$. Furthermore, all sample dilution curves were parallel with the standard curves, indicating the absence of nonspecific inhibitors in the extracts.

In Expt. 3, ${ }^{14} \mathrm{CO}_{2}$ was fed to the leaves of $\mathrm{R}_{1}, \mathrm{R}_{2}$, and $\mathrm{R}_{3}$ ramets, respectively, at the initiation of each PEG treatment to monitor the translocation of photosynthate. A superscript $L$ was added to $\mathrm{R}_{3} \mathrm{R}_{2} \mathrm{R}_{1}$ to denote ${ }^{14} \mathrm{C}$ label. The treatments were arranged in a randomized complete block design with three replications. Each treatment unit contained three plants. The ramet to be labeled was first enclosed in an air-tight transparent polyvinylchloride gas-sampling bag $(20 \times 5 \mathrm{~cm})$, and $10 \mathrm{~mL}$ of ${ }^{14} \mathrm{CO}_{2}$ was injected into each bag through a septum stopper via a syringe and needle. The ${ }^{14} \mathrm{CO}_{2}$ was generated by adding $0.1 \mathrm{M}$ $\mathrm{H}_{2} \mathrm{SO}_{4}$ into a vial containing $\mathrm{NaH}^{14} \mathrm{CO}_{3}(749 \mathrm{kBq})$ (PerkinElmer, Waltham, MA). The air in the bags was pumped out and the residual ${ }^{14} \mathrm{CO}_{2}$ was absorbed by soda lime after the ramets were incubated in ${ }^{14} \mathrm{CO}_{2}$ for $30 \mathrm{~min}$. Four hours after ${ }^{14} \mathrm{CO}_{2}$ labeling, the shoots, roots, and internodes were harvested and immediately oven-dried at 95 to $100{ }^{\circ} \mathrm{C}$ for $10 \mathrm{~min}$ and then at $80{ }^{\circ} \mathrm{C}$ for $48 \mathrm{~h}$. The samples were ground with a mortar and pestle and were then measured with a BH1216 low-background $\alpha, \beta$-scintillation counter (Beijing Nuclear Instrument, Beijing, China). The sample radioactivity was expressed as counts per gram of dry tissue. The percentage of ${ }^{14} \mathrm{CO}_{2}$-labeled photosynthate in each part of the ramet was adjusted by the percentage of weight relative to the whole plant.

The data were subjected to analysis of variance (ANOVA) using the general linear model in SAS (version 9.1; SAS Institute, Cary, NC). Fisher's protected least significant difference (LSD) values were calculated. Percentage data were subjected to arcsine square-root transformations before the analysis, and final results were converted to the non-transformed values for clarity.

\section{Results and Discussion}

When acid fuchsin was added to the culture solution of a ramet, the shoot and roots of that ramet were always dyed regardless of the water stress from PEG (Table 1). When none of the three connected ramets were under water stress, the acid fuchsin moved from older ramet to younger ramet (Table 1). When a ramet was under water stress from PEG, in addition to apical movement, the dye also moved toward the shoot of the stressed ramet, as shown from the comparisons $\mathrm{R}_{3}{ }^{\mathrm{P}} \mathrm{R}_{2}{ }^{\mathrm{D}} \mathrm{R}_{1}$ versus $R_{3} R_{2}{ }^{D} R_{1}, R_{3}{ }^{P} R_{2} R_{1}{ }^{D}$ versus $R_{3} R_{2} R_{1}{ }^{D}$, and $R_{3} R_{2}{ }^{P} R_{1}{ }^{D}$ versus $R_{3} R_{2} R_{1}{ }^{D}$ (Table 1 ). When an older ramet was stressed, the apical movement of dye was suppressed, as shown in comparisons of $R_{3}{ }^{P D} R_{2} R_{1}$ versus $R_{3}{ }^{D} R_{2} R_{1}$ and $R_{3} R_{2}{ }^{P D} R_{1}$ versus $R_{3} R_{2}{ }^{D} R_{1}$ (Table 1). Therefore, our results indicated that interramet water integration happened when one of the connected ramets was under water stress, though it also seems that integration occurs without water stress if ramets differ in age. In other words, integration is one-way in some cases.

The statistical results from ANOVA showed that there were significant differences for the endogenous hormone concentration in the shoots and roots among treatments (Table 2) as well as the shoot/root ratio of endogenous hormones (Table 3).

The content of ZR decreased in PEG-treated roots, but increased in the roots of untreated youngest ramets, as in $R_{3}{ }^{P} R_{2} R_{1}$ and $R_{3} R_{2}{ }^{P} R_{1}$, or untreated older ramets, as in $R_{3} R_{2} R_{1}{ }^{P}$ (Table 2). However, because ZR is mainly synthesized in roots (Chen et al., 1985), it is unclear whether the decreased content in treated roots was because of inhibition or accelerated output. The levels of ZR in shoots were increased compared with the untreated control except in the shoot of $R_{3}$ and $R_{1}$ in the treatment $R_{3} R_{2} R_{1}{ }^{P}$. The low content of $Z R$ in the $R_{3}$ shoot may be due to the increased transport stream within the vascular bundle from $\mathrm{R}_{3}$ roots to younger ramets (Table 1 ). The shoot/ root ratios of $\mathrm{ZR}$ content were all increased compared with the control except for the youngest ramet in treatment $R_{3} R_{2} R_{1}{ }^{P}$, where the roots of the youngest ramets were treated with $P E G$ (Fig. 2).

The ABA content in shoot was increased in $\mathrm{R}_{3}{ }^{\mathrm{P}} \mathrm{R}_{2} \mathrm{R}_{1}$ and $\mathrm{R}_{3} \mathrm{R}_{2}{ }^{\mathrm{P}} \mathrm{R}_{1}$ treatments compared with the control (Table 2 ). When 
Table 1. Presence of red color in the shoot, roots, and internodes in three connected ramets of 'Texoka' buffalograss after adding $0.7 \%$ acidic fuchsin dye to one of the culture solutions of the three ramets and applying osmotic stress with polyethylene glycol (PEG-8000; Sigma-Aldrich, St. Louis) at one ramet.

\begin{tabular}{|c|c|c|c|c|c|c|c|c|}
\hline \multirow[b]{2}{*}{ Treatment ${ }^{z}$} & \multicolumn{2}{|c|}{$\mathrm{R}_{3}{ }^{\mathrm{y}}$} & \multirow[b]{2}{*}{ Internode } & \multicolumn{2}{|c|}{$\mathrm{R}_{2}$} & \multirow[b]{2}{*}{ Internode } & \multicolumn{2}{|c|}{$\mathrm{R}_{1}$} \\
\hline & Shoot & Root & & Shoot & $\overline{\text { Root }}$ & & Shoot & Root \\
\hline $\mathrm{R}_{3}{ }^{\mathrm{D}} \mathrm{R}_{2} \mathrm{R}_{1}$ & $++^{x}$ & + & + & + & - & + & + & - \\
\hline $\mathrm{R}_{3} \mathrm{R}_{2}{ }^{\mathrm{D}} \mathrm{R}_{1}$ & - & - & + & ++ & + & - & + & - \\
\hline $\mathrm{R}_{3} \mathrm{R}_{2} \mathrm{R}_{1}{ }^{\mathrm{D}}$ & - & - & - & - & - & + & ++ & + \\
\hline $\mathrm{R}_{3}{ }^{\mathrm{PD}} \mathrm{R}_{2} \mathrm{R}_{1}$ & ++ & + & + & + & - & - & - & - \\
\hline $\mathrm{R}_{3}{ }^{\mathrm{P}} \mathrm{R}_{2}{ }^{\mathrm{D}} \mathrm{R}_{1}$ & + & - & + & ++ & + & - & + & - \\
\hline $\mathrm{R}_{3}{ }^{\mathrm{P}} \mathrm{R}_{2} \mathrm{R}_{1}{ }^{\mathrm{D}}$ & + & - & - & + & - & - & ++ & + \\
\hline $\mathrm{R}_{3}{ }^{\mathrm{D}} \mathrm{R}_{2}{ }^{\mathrm{P}} \mathrm{R}_{1}$ & ++ & + & + & ++ & - & - & + & - \\
\hline $\mathrm{R}_{3} \mathrm{R}_{2}{ }^{\mathrm{PD}} \mathrm{R}_{1}$ & - & - & - & ++ & + & - & - & - \\
\hline $\mathrm{R}_{3} \mathrm{R}_{2}{ }^{\mathrm{P}} \mathrm{R}_{1}{ }^{\mathrm{D}}$ & - & - & - & + & - & + & ++ & + \\
\hline $\mathrm{R}_{3}{ }^{\mathrm{D}} \mathrm{R}_{2} \mathrm{R}_{1}{ }^{\mathrm{P}}$ & ++ & + & + & ++ & - & + & + & - \\
\hline $\mathrm{R}_{3} \mathrm{R}_{2}{ }^{\mathrm{D}} \mathrm{R}_{1}{ }^{\mathrm{P}}$ & - & - & - & ++ & + & + & + & - \\
\hline $\mathrm{R}_{3} \mathrm{R}_{2} \mathrm{R}_{1}{ }^{\mathrm{PD}}$ & - & - & - & - & - & - & + & + \\
\hline
\end{tabular}

${ }^{z}$ The superscript D indicates acid fuchsin dye added to the Hoagland solution of the ramet. The superscript $\mathrm{P}$ indicates osmotic stress applied to the roots of a ramet cultured in Hoagland solution with 30\% PEG-8000.

${ }^{y} R_{3}, R_{2}$, and $R_{1}$, represent the oldest, second, and youngest ramet, respectively.

$\mathrm{x}_{++},+$indicate dark and light red colors, respectively; and - indicates absent of red color.

Table 2. Endogenous hormone concentration in the organs of three connected ramets of 'Texoka' buffalograss with the roots of one of the ramets treated with $30 \%$ polyethylene glycol (PEG- 8000 ; Sigma-Aldrich, St. Louis).

\begin{tabular}{|c|c|c|c|c|c|c|}
\hline \multirow[b]{2}{*}{ Treatment $^{z}$} & Shoot $3^{y}$ & Shoot 2 & Shoot 1 & Root $3^{x}$ & Root 2 & Root 1 \\
\hline & \multicolumn{6}{|c|}{ Hormone concn $\left(\mu \mathrm{g} \cdot \mathrm{kg}^{-1}\right.$ fresh wt) } \\
\hline & \multicolumn{6}{|c|}{$\mathrm{ZR}^{\mathrm{w}}$} \\
\hline $\mathrm{R}_{3} \mathrm{R}_{2} \mathrm{R}_{1}$ & $186.6 \mathrm{c}^{\mathrm{v}}$ & $206.5 \mathrm{c}$ & $181.4 \mathrm{c}$ & $212.4 \mathrm{~b}$ & $177.4 \mathrm{~b}$ & $267.3 \mathrm{c}$ \\
\hline $\mathrm{R}_{3}{ }^{\mathrm{P}} \mathrm{R}_{2} \mathrm{R}_{1}$ & $267.9 \mathrm{~b}$ & $261.7 \mathrm{~b}$ & $396.1 \mathrm{a}$ & $180.6 \mathrm{c}$ & $120.4 \mathrm{c}$ & $381.5 \mathrm{a}$ \\
\hline $\mathrm{R}_{3} \mathrm{R}_{2}{ }^{\mathrm{P}} \mathrm{R}_{1}$ & $291.6 \mathrm{a}$ & $254.1 \mathrm{~b}$ & $357.0 \mathrm{~b}$ & $116.5 \mathrm{~d}$ & $91.0 \mathrm{~d}$ & $332.3 \mathrm{~b}$ \\
\hline \multirow[t]{2}{*}{$\mathrm{R}_{3} \mathrm{R}_{2} \mathrm{R}_{1}{ }^{\mathrm{P}}$} & $155.6 \mathrm{~d}$ & $288.6 \mathrm{a}$ & $159.6 \mathrm{~d}$ & $283.9 \mathrm{a}$ & $226.1 \mathrm{a}$ & $112.6 \mathrm{~d}$ \\
\hline & \multicolumn{6}{|c|}{$\mathrm{ABA}$} \\
\hline $\mathrm{R}_{3} \mathrm{R}_{2} \mathrm{R}_{1}$ & $482.4 \mathrm{~b}$ & $787.0 \mathrm{c}$ & $708.2 \mathrm{c}$ & $279.4 \mathrm{~d}$ & $377.0 \mathrm{~d}$ & $161.3 \mathrm{~d}$ \\
\hline $\mathrm{R}_{3}{ }^{\mathrm{P}} \mathrm{R}_{2} \mathrm{R}_{1}$ & $675.8 \mathrm{a}$ & $771.3 \mathrm{c}$ & $1187.5 \mathrm{~b}$ & $410.8 \mathrm{c}$ & $543.1 \mathrm{c}$ & $575.9 \mathrm{~b}$ \\
\hline $\mathrm{R}_{3} \mathrm{R}_{2}{ }^{\mathrm{P}} \mathrm{R}_{1}$ & $688.3 \mathrm{a}$ & $1104.0 \mathrm{a}$ & $1531.4 \mathrm{a}$ & $1021.7 \mathrm{a}$ & $1532.3 \mathrm{a}$ & $1231.0 \mathrm{a}$ \\
\hline \multirow[t]{2}{*}{$\mathrm{R}_{3} \mathrm{R}_{2} \mathrm{R}_{1}{ }^{\mathrm{P}}$} & $437.4 \mathrm{c}$ & $878.1 \mathrm{~b}$ & $689.6 \mathrm{~d}$ & $827.7 \mathrm{~b}$ & 841.6 b & $535.1 \mathrm{c}$ \\
\hline & \multicolumn{6}{|c|}{ IAA } \\
\hline $\mathrm{R}_{3} \mathrm{R}_{2} \mathrm{R}_{1}$ & $508.5 \mathrm{a}$ & $636.6 \mathrm{a}$ & $692.5 \mathrm{a}$ & $379.0 \mathrm{a}$ & $507.7 \mathrm{a}$ & $373.0 \mathrm{a}$ \\
\hline $\mathrm{R}_{3}{ }^{\mathrm{P}} \mathrm{R}_{2} \mathrm{R}_{1}$ & $109.7 \mathrm{~d}$ & $378.2 \mathrm{~b}$ & $492.1 \mathrm{~b}$ & $143.8 \mathrm{~b}$ & $197.8 \mathrm{~d}$ & $369.4 \mathrm{a}$ \\
\hline $\mathrm{R}_{3} \mathrm{R}_{2}{ }^{\mathrm{P}} \mathrm{R}_{1}$ & $183.9 \mathrm{c}$ & $145.5 \mathrm{~d}$ & $348.2 \mathrm{~d}$ & $101.4 \mathrm{c}$ & $212.0 \mathrm{c}$ & $258.4 \mathrm{c}$ \\
\hline \multirow[t]{2}{*}{$\mathrm{R}_{3} \mathrm{R}_{2} \mathrm{R}_{1}{ }^{\mathrm{P}}$} & $230.9 \mathrm{~b}$ & $310.2 \mathrm{c}$ & $366.4 \mathrm{c}$ & $374.3 \mathrm{a}$ & $388.8 \mathrm{~b}$ & $341.6 \mathrm{~b}$ \\
\hline & \multicolumn{6}{|c|}{ GAs } \\
\hline $\mathrm{R}_{3} \mathrm{R}_{2} \mathrm{R}_{1}$ & $195.8 \mathrm{c}$ & $292.6 \mathrm{c}$ & $255.6 \mathrm{~d}$ & $203.4 \mathrm{c}$ & $139.2 \mathrm{~d}$ & $132.9 \mathrm{~d}$ \\
\hline $\mathrm{R}_{3}{ }^{\mathrm{P}} \mathrm{R}_{2} \mathrm{R}_{1}$ & $194.0 \mathrm{c}$ & $498.3 \mathrm{a}$ & $767.4 \mathrm{~b}$ & $459.4 \mathrm{~b}$ & $411.8 \mathrm{c}$ & $348.8 \mathrm{c}$ \\
\hline $\mathrm{R}_{3} \mathrm{R}_{2}{ }^{\mathrm{P}} \mathrm{R}_{1}$ & $337.7 \mathrm{~b}$ & $493.2 \mathrm{a}$ & $929.8 \mathrm{a}$ & $582.2 \mathrm{a}$ & $828.5 \mathrm{a}$ & $670.5 \mathrm{a}$ \\
\hline $\mathrm{R}_{3} \mathrm{R}_{2} \mathrm{R}_{1}{ }^{\mathrm{P}}$ & $460.1 \mathrm{a}$ & $351.0 \mathrm{~b}$ & $640.0 \mathrm{c}$ & $545.2 \mathrm{a}$ & $505.0 \mathrm{~b}$ & $446.4 \mathrm{~b}$ \\
\hline
\end{tabular}

${ }^{\mathrm{z}} \mathrm{R}_{3}, \mathrm{R}_{2}$, and $\mathrm{R}_{1}$, represent the oldest, second, and youngest ramets, respectively. The superscript $\mathrm{P}$ indicates osmotic stress applied to the ramet cultured in Hoagland solution with $30 \%$ PEG- 8000 .

${ }^{y}$ Shoot 1 , shoot 2 , and shoot 3 belong to the youngest, second, and oldest ramet, respectively.

${ }^{x}$ Root 1 , root 2 , and root 3 belong to the youngest, second, and oldest ramet, respectively.

wZR, ABA, IAA, and GAs represent transzeatin riboside, abscisic acid, indole-3-acetic acid, and gibberellic acid, respectively.

vame letter indicates no significant difference at the $0.01 P$ level.

the roots of the youngest ramet were treated with PEG, the ABA content was not increased in the oldest and youngest shoot, but only increased in the middle shoot, indicating a different pattern of translocation. However, ABA content was increased in the roots of all treatments compared with the control (Table 2). The shoot/root ratios of ABA were decreased in all treatments compared with the control (Fig. 2). This overall increase of ABA content in roots or decrease in shoot/root ratio was probably because $\mathrm{ABA}$ is mainly a stress hormone (Guy, 1990; Hasegawa et al., 1987; Tanino et al., 1990; Zhang and Davies, 1989) and can be transported in xylem and phloem and also in parenchyma cells outside the vascular bundles (Salisbury and Ross, 1992).

Water stress in one of the three ramets from PEG caused reduction of IAA content in shoots and roots, especially in the ramet being stressed (Table 2). As a result, the ratio of IAA levels between shoot and root also changed. When the $\mathrm{R}_{3}$ ramet was stressed, the shoot-toroot ratio of IAA in the $R_{2}$ ramet increased, while the ratios in $R_{1}$ and $\mathrm{R}_{3}$ decreased compared with nonstressed control (Fig. 2). When the $\mathrm{R}_{2}$ ramet was stressed, the shoot-toroot ratio of IAA in the $R_{3}$ ramet increased, while the ratios in $R_{1}$ and $\mathrm{R}_{2}$ decreased compared with the non-stressed control (Fig. 2). When the $\mathrm{R}_{1}$ ramet was stressed, the shootto-root ratios of IAA in all ramets decreased compared with the nonstressed control (Fig. 2). Because IAA transportation is usually in the parenchyma cells at a relatively slow speed (Salisbury and Ross, 1992), it is not clear if the changes were due to direct inter-ramet integration of IAA.

The GA content in shoots and roots of all treatments increased compared with the control (Table $2)$. It is not clear whether this was due to upregulation of GA synthesis in shoots and roots or transport from connected ramets. The shoot/root ratio of GAs decreased in all ramets in the $R_{3} R_{2}{ }^{P} R_{1}$ treatment. In $\mathrm{R}_{3}{ }^{\mathrm{P}} \mathrm{R}_{2} \mathrm{R}_{1}$ and $\mathrm{R}_{3} \mathrm{R}_{2} \mathrm{R}_{1}{ }^{\mathrm{P}}$ treatments, the ratio decreased for the two ramets that were not treated with PEG, and remained at the level of the control for the ramet that was treated with PEG (Fig. 2). The distribution and allocation of endogenous hormones were shown to be affected by differential water stress in the interconnected ramets. Those hormones may be responsible for the regulation of the physiological integration, although the mechanisms were not clear. 
Table 3. Analysis of variance of the shoot/root ratios of endogenous hormone concentration in the ramets of 'Texoka' buffalograss with the roots of one of the three connected ramets treated with $30 \%$ polyethylene glycol (PEG-8000; Sigma-Aldrich, St. Louis).

\begin{tabular}{|c|c|c|c|c|c|c|c|}
\hline \multirow[b]{2}{*}{ Source } & \multirow[b]{2}{*}{ DF } & \multicolumn{2}{|c|}{$\mathrm{R}_{1}^{\mathrm{z}}$} & \multicolumn{2}{|c|}{$\mathrm{R}_{2}$} & \multicolumn{2}{|c|}{$\mathrm{R}_{3}$} \\
\hline & & $\mathrm{F}$ & $P>\mathrm{F}$ & $\mathrm{F}$ & $P>\mathrm{F}$ & $\mathrm{F}$ & $P>\mathrm{F}$ \\
\hline & & \multicolumn{6}{|c|}{$\mathrm{ZR}^{\mathrm{y}}$} \\
\hline Replication & 2 & 4.23 & 0.0713 & 0.42 & 0.6748 & 5.79 & 0.0398 \\
\hline Stress & 3 & 1018.96 & $<0.0001$ & 914.55 & $<0.0001$ & 4660.13 & $<0.0001$ \\
\hline \multirow[t]{2}{*}{$\mathrm{CV}(\%)^{\mathrm{x}}$} & & 1.56 & & 2.39 & & 1.61 & \\
\hline & & \multicolumn{6}{|c|}{$\mathrm{ABA}$} \\
\hline Replication & 2 & 0.14 & 0.8714 & 0.06 & 0.9391 & 0.23 & 0.8024 \\
\hline Stress & 3 & 164.16 & $<0.0001$ & 319.16 & $<0.0001$ & 4362.84 & $<0.0001$ \\
\hline \multirow[t]{2}{*}{ CV (\%) } & & 9.36 & & 4.32 & & 1.44 & \\
\hline & & \multicolumn{6}{|c|}{ IAA } \\
\hline Replication & 2 & 0.07 & 0.934 & 1.69 & 0.2612 & 1.56 & 0.2847 \\
\hline Stress & 3 & 115.46 & $<0.0001$ & 809.26 & $<0.0001$ & 794.03 & $<0.0001$ \\
\hline \multirow[t]{2}{*}{ CV (\%) } & & 3.78 & & 2.94 & & 2.99 & \\
\hline & & \multicolumn{6}{|c|}{ GAs } \\
\hline Replication & 2 & 0.00 & 0.9969 & 0.15 & 0.8619 & 2.12 & 0.2008 \\
\hline Stress & 3 & 25.28 & 0.0008 & 454.12 & $<0.0001$ & 48.11 & 0.0001 \\
\hline CV (\%) & & 7.80 & & 4.87 & & 8.79 & \\
\hline
\end{tabular}

${ }^{\mathrm{z}} \mathrm{R}_{3}, \mathrm{R}_{2}$, and $\mathrm{R}_{1}$, represent the oldest, second, and youngest ramet, respectively.

YZR, ABA, IAA, and GAs represent transzeatin riboside, abscisic acid, indole-3-acetic acid, and gibberellic acid, respectively.

${ }^{\mathrm{x}}$ Coefficient of variation.
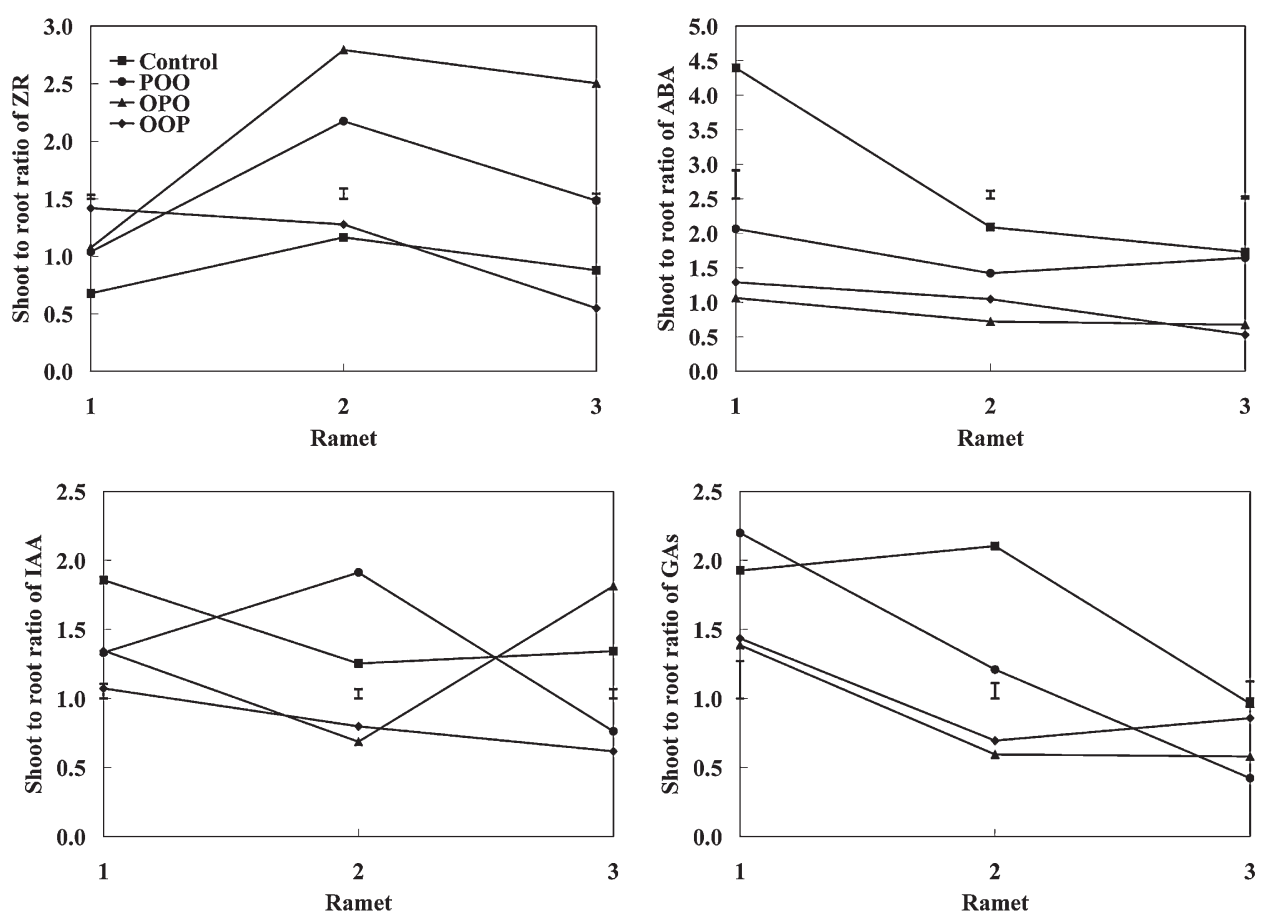

Fig. 2. Shoot-to-root ratio of endogenous hormone concentration $\left(\mu \mathrm{g} \cdot \mathrm{kg}^{-1}\right.$ fresh wt) in the ramets of 'Texoka' buffalograss. POO, OPO, and OOP are the $\mathrm{R}_{3}{ }^{\mathrm{P}} \mathrm{R}_{2} \mathrm{R}_{1}, \mathrm{R}_{3} \mathrm{R}_{2}{ }^{\mathrm{P}} \mathrm{R}_{1}$, and $\mathrm{R}_{3} \mathrm{R}_{2} \mathrm{R}_{1}{ }^{\mathrm{P}}$ treatments, respectively. $\mathrm{R}_{3}, \mathrm{R}_{2}$, and $\mathrm{R}_{1}$ represent the oldest, second, and youngest ramet, respectively, and the superscript P represents PEG-8000 (previously named PEG-6000; Sigma-Aldrich, St. Louis) treatment in the roots. Vertical bar represents Fisher's protected least significant difference at the $0.05 P$ level. ZR, ABA, IAA, and GAs represent transzeatin riboside, abscisic acid, indole-3-acetic acid, and gibberellic acid, respectively.

The distribution of ${ }^{14} \mathrm{C}$-labeled photosynthate was not only different between different treatments, but was also affected by the location of labeling (Table 4). When the oldest ramet was under water stress, transport of labeled photosynthate was not detected from the youngest ramet to the roots and shoots of older ramets when the youngest was labeled; however, translocation was found from the shoot of the second ramet to the shoot of the third ramet (Table 5). Yet, in $R_{3}{ }^{\mathrm{PL}} \mathrm{R}_{2} \mathrm{R}_{1}$, translocation of labeled photosynthate was detected from the shoot of the third ramet to the second ramet. This indicated that the youngest ramet was the sink, but when the oldest ramet was under stress, there might be photosynthate translocation toward the old ramet. The increased translocation of labeled photosynthate toward the shoot of stressed ramet also was shown in treatments $\mathrm{R}_{3} \mathrm{R}_{2}{ }^{\mathrm{P}} \mathrm{R}_{1}{ }^{\mathrm{L}}$ and $\mathrm{R}_{3}{ }^{\mathrm{L}} \mathrm{R}_{2}{ }^{\mathrm{P}} \mathrm{R}_{1}$. The photosynthate retention in and translocation to the stressed roots were increased when the roots of the second ramet were stressed. When the roots of the youngest ramet were under stress, the photosynthate retention and translocation to the shoot of stressed ramet increased compared with the control (Table $5)$. While the translocation of photosynthate toward the stressed ramets was increased, the partition to the youngest ramet was in shoot and root, but the partition to the oldest ramet was more in the shoot. This pattern of source-sink relationship also was reported in red clover (Trifolium repens) (Ryle et al., 1981).

Unlike in the case of timothy grass (Phluem pretense), where defoliation stress had a minor effect on the distribution of labeled photosynthate to the predetermined sink structure (St. Pierre and Wright, 1972), the transport of photosynthate in buffalograss under differentiated water stress demonstrated a strong integration toward stressed ramets, although the test was only conducted $4 \mathrm{~h}$ after the labeling.

The above results showed that buffalograss was able to integrate according to the new source-sink relationship under heterogeneous conditions. Therefore, the fate of connected ramets was not independent in this clonal species. Even for established populations as in turf areas, the advantage may be still significant as long as the ramets are connected. Although the agronomic significance of this characteristic needs further evaluation, from a botanical point of view, the "phalanx"-type may create higher shoot density in turf because of the intensive 
Table 4. Analysis of variance of the ${ }^{14} \mathrm{C}$ labeled photosynthates transportation among the ramets of 'Texoka' buffalograss with the roots of one of the three connected ramets treated with 30\% PEG-8000 (previously named PEG-6000, Sigma-Aldrich, St. Louis, MO).

\begin{tabular}{|c|c|c|c|c|c|c|c|c|c|c|c|c|c|}
\hline \multirow[b]{2}{*}{ Source } & \multirow[b]{2}{*}{ DF } & \multicolumn{2}{|c|}{ Shoot $1^{z}$} & \multicolumn{2}{|c|}{ Shoot 2} & \multicolumn{2}{|c|}{ Shoot 3} & \multicolumn{2}{|c|}{ Root $1^{y}$} & \multicolumn{2}{|c|}{ Root 2} & \multicolumn{2}{|c|}{ Root 3} \\
\hline & & $\mathrm{F}$ & $P>\mathrm{F}$ & $\mathrm{F}$ & $P>\mathrm{F}$ & $\mathrm{F}$ & $P>\mathrm{F}$ & $F$ & $P>\mathrm{F}$ & $\mathrm{F}$ & $P>\mathrm{F}$ & $\mathrm{F}$ & $P>\mathrm{F}$ \\
\hline Replication & 2 & 0.6 & 0.5781 & 1.5 & 0.2535 & 2.2 & 0.1340 & 0.6 & 0.5790 & 1.1 & 0.3389 & 0.4 & 0.6847 \\
\hline $\begin{array}{l}\text { Stress location } \\
\text { (S) }\end{array}$ & 3 & 37.8 & $<0.0001$ & 32.6 & $<0.0001$ & 47.0 & $<0.0001$ & 105.6 & $<0.0001$ & 82.3 & $<0.0001$ & 185.9 & $<0.0001$ \\
\hline $\begin{array}{l}\text { Label location } \\
\text { (L) }\end{array}$ & 2 & $25,203.2$ & $<0.0001$ & $24,695.2$ & $<0.0001$ & $23,420.0$ & $<0.0001$ & 634.7 & $<0.0001$ & 516.4 & $<0.0001$ & 932.5 & $<0.0001$ \\
\hline $\mathrm{S} \times \mathrm{L}$ & 6 & 48.7 & $<0.0001$ & 23.4 & $<0.0001$ & 14.1 & $<0.0001$ & 140.5 & $<0.0001$ & 82.3 & $<0.0001$ & 350.6 & $<0.0001$ \\
\hline
\end{tabular}

${ }^{\mathrm{z}}$ Shoot 1 , shoot 2 , and shoot 3 belong to the youngest, second, and oldest ramet, respectively.

${ }^{\mathrm{y}}$ Root 1 , root 2 , and root 3 belong to the youngest, second, and oldest ramet, respectively.

${ }^{\mathrm{x}} \mathrm{CV}$ is coefficient of variation.

Table 5. ${ }^{14} \mathrm{C}$-labeled photosynthate transport among connected ramets of 'Texoka' buffalograss when one ramet was under osmotic stress with $30 \%$ polyethylene glycol (PEG-8000; Sigma-Aldrich, St. Louis). Data presented are percentage of radioactivity in parts relative to the whole plant.

\begin{tabular}{|c|c|c|c|c|c|c|}
\hline \multirow[b]{2}{*}{ Treatment $^{z}$} & $y^{y}$ & hoot 2 & Shoot 1 & Root $3^{x}$ & Root 2 & Roo \\
\hline & \multicolumn{6}{|c|}{ Radioactivity (\% whole plant) } \\
\hline $\mathrm{R}_{3} \mathrm{R}_{2} \mathrm{R}_{1}{ }^{\mathrm{L}}$ & 0.047 & 0.048 & 84.154 & 0.001 & 0.002 & 14.2 \\
\hline${ }_{3} \mathrm{R}_{2}{ }^{\mathrm{L}} \mathrm{R}_{1}$ & 142 & 94.774 & 0 . & 0.059 & & 0.1 \\
\hline${ }_{3}^{\mathrm{L}} \mathrm{R}_{2} \mathrm{R}_{1}$ & 89.256 & 0.000 & 0.000 & 7.977 & 0.000 & 0.00 \\
\hline $\mathrm{R}_{3}{ }^{\mathrm{P}} \mathrm{R}_{2} \mathrm{R}_{1}{ }^{\mathrm{L}}$ & 14 & .027 & 95.328 & 0.005 & 0.000 & 2.4 \\
\hline${ }_{3}^{\mathrm{P}} \mathrm{R}_{2}{ }^{\mathrm{L}} \mathrm{R}_{1}$ & 0.232 & 93.830 & 0.002 & 0.050 & 1.107 & 0.0 \\
\hline $\mathrm{R}_{3}{ }^{\mathrm{PL}} \mathrm{R}_{2} \mathrm{R}_{1}$ & 95.477 & 0.245 & 0.054 & 1.325 & 0.067 & 0.0 \\
\hline${ }_{3} \mathrm{R}_{2}{ }^{\mathrm{P}} \mathrm{R}_{1}{ }^{\mathrm{L}}$ & 2 & 076 & 96.468 & 0.000 & 0 . & 1.2 \\
\hline${ }_{3} \mathrm{R}_{2}{ }^{\mathrm{PL}} \mathrm{R}_{1}$ & 7 & 90.368 & 76 & 0 . & & 0.0 \\
\hline $\mathrm{R}_{3}{ }^{\mathrm{L}} \mathrm{R}_{2}{ }^{\mathrm{P}} \mathrm{R}_{1}$ & 94. & 7 & & & & 0.2 \\
\hline $\mathrm{R}_{3} \mathrm{R}_{2} \mathrm{R}_{1}{ }^{\mathrm{PL}}$ & 0.009 & 0.015 & 97.012 & 0.011 & 0.003 & 0.2 \\
\hline $\mathrm{R}_{3} \mathrm{R}_{2}{ }^{\mathrm{L}} \mathrm{R}_{1}{ }^{\mathrm{P}}$ & 0.004 & 98.552 & & 0.025 & 0.405 & 0.1 \\
\hline $\mathrm{R}_{3}{ }^{\mathrm{L}} \mathrm{R}_{2} \mathrm{R}_{1}{ }^{\mathrm{P}}$ & 97.192 & 0.0 & 95 & 0.177 & 0.003 & 0.0 \\
\hline $\mathrm{LSD}_{0.05}{ }^{\mathrm{w}}$ & 0.014 & 0.014 & 0.014 & 0.006 & 0.010 & 0.0 \\
\hline
\end{tabular}

${ }^{\mathrm{z}} \mathrm{R} 3, \mathrm{R} 2$, and R1, represent the oldest, second, and youngest ramets, respectively; $\mathrm{L}$ indicates ${ }^{14} \mathrm{C}$-label; $\mathrm{P}$ indicates osmotic stress applied to the ramet cultured in Hoagland solution with $30 \%$ PEG- 8000 .

${ }^{y}$ Shoot 1 , shoot 2, and shoot 3 belong to the youngest, second, and oldest ramet, respectively.

${ }^{x}$ Root 1 , root 2, and root 3 belong to the youngest, second, and oldest ramet, respectively.

${ }^{\text {w}}$ Fisher's protected least significant difference at the $0.05 P$ level.

growth habit. From the turfgrass management aspect, however, it may be desirable to have strong "guerilla"-type clonal plants (long nodes and extensive growth) (Lovett Doust, 1981) that can share resources and form uniform turf. Therefore, in the breeding process, an intermediate spreading type of buffalograss plant might have better potential than the "phalanx" and "guerilla" types for the improvement of turf uniformity and shoot density because it combines the advantages of physiological integration with vertical growing vigor.

\section{Literature Cited}

Abreu, M.E. and S. Munne-Bosch. 2008. Salicylic acid may be involved in the regulation of drought-induced leaf senescence in perennials: A case study in field-grown Salvia officinalis L. plants. Environ. Exp. Bot. 64:105-112.

Alpert, P. 1991. Nitrogen sharing among ramets increases clonal growth in Fragaria chiloensis. Ecology 72:69-80.
Alpert, P. and H.A. Mooney. 1986. Resource sharing among ramets in the clonal herb, Fragaria chiloensis. Oecologia 70:227-233.

Alpert, P., C. Holzapfel, and J.M. Benson. 2002. Hormonal modification of resource sharing in the clonal plant Fragaria chiloensis. Funct. Ecol. 16:191-197.

Baum, S.F., P.N. Tran, and W.K. Silk. 2000. Effects of salinity on xylem structure and water use in growing leaves of sorghum. New Phytol. 146:119-127.

Beard, J.B. 1985. Turfgrass physiology research 1981-85. Intl. Turfgrass Soc. Res. J. 5:81-104.

Bradshaw, A.D. 1965. Evolutionary significance of phenotypic plasticity in plants. Adv. Genet. 13:115-155.

Casler, M.D. and R.R. Duncan. 2003. Origins of the turfgrasses, p. 523. In: M.D. Casler and R.R. Duncan (eds.). Turfgrass biology, genetics, and breeding. Wiley, Hoboken, NJ.

Chen, C.M., J.R. Ertl, S.M. Leisner, and C.C. Chang. 1985. Localization of cytokinin biosynthetic sites in pea plants and carrot roots. Plant Physiol. 78:510-513.

DiPaola, J.M., K.J. Karnok, and J.B. Beard. 1981. Growth, color, and chloroplast pigment content of bermudagrass turfs under chilling conditions as influenced by gibberellic acid. Intl. Turfgrass Soc. Res. J. 4:527-534.

Forde, B.J. 1966. Translocation in grasses. I. Bermuda grass. N.Z. J. Bot. 4:479-495.

Frank, K.W., R.E. Gaussoin, T.P. Riordan, R.C. Shearman, J.D. Fry, E.D. Miltner, and P.G. Johnson. 2004. Nitrogen rate and mowing height effects on turf-type buffalograss. Crop Sci. 44:1615-1621.

Guy, C.L. 1990. Cold acclimation and freezing stress tolerance: Role of protein metabolism. Annu. Rev. Plant Physiol. Plant Mol. Biol. 41:187-233.

Hasegawa, P.M., R.A. Bressan, and A.K. Handa. 1987. Cellular mechanism of salinity tolerance. HortScience 21:1317-1324.

Hellström, K., M. Kytöviita, J. Tuomi, and P. Rautio. 2006. Plasticity of clonal integration in the perennial herb Linaria vulgaris after damage. Funct. Ecol. 20:413-420.

Hothem, S.D., K.A. Marley, and R.A. Larson. 2003. Photochemistry in Hoagland's nutrient solution. J. Plant Nutr. 26:845-854.

Huang, B. 1999. Water relations and root activities of Buchloe dactyloides and Zoysia japonica in response to localized soil drying. Plant Soil 208:179-186.

Huff, D.R. and L. Wu. 1987. Sex expression in buffalograss under different environments. Crop Sci. 27:623-626.

Jackson, J.B.C. 1979. Morphological strategies of sessile animals, p. 499-555. In: G. Larwood and B.R. Rosen (eds.). Biology and systematic of colonial organisms. Academic Press, London.

Jia, W., J. Zhang, and J. Liang. 2001. Initiation and regulation of water deficit-induced abscisic acid accumulation in maize leaves and roots: Cellular volume and water relations. J. Expt. Bot. 52:295-300.

Jiang, M. and J. Zhang. 2002. Water stress-induced abscisic acid accumulation triggers the increased generation of reactive oxygen 
species and up-regulates the activities of antioxidant enzymes in maize leaves. J. Expt. Bot. 379:2401-2410.

Johnson, P.G., P.P. Riordan, and J. Johnson-Cicalese. 2000. Lowmowing tolerance in buffalograss. Crop Sci. 40:1339-1343.

Kaitaniemi, P. and T. Honkanen. 1996. Simulating source-sink control of carbon and nutrient translocation in a modular plant. Ecol. Modell. 88:227-240.

Karnok, K. and K.A. Tucker. 2001. Wetting agent treated hydrophobic soil and its effect of color, quality and root growth of creeping bentgrass. Intl. Turfgrass Soc. Res. J. 9:537-541.

Kroon, H., B. Fransen, W.A. Rheenen, A. Dijk, and R. Kreulen. 1996. High levels of inter-ramet water translocation in two rhizomatous Carex species, as quantified by deuterium labeling. Oecologia 106:73-84.

Liu, X. and B. Huang. 2002. Cytokinin effects on creeping bentgrass responses to heat stress II. Antioxidant enzyme activities and lipid peroxidation. Crop Sci. 42:466-472.

Lovett Doust, L. 1981. Interclonal variation and competition in Ranunculus repens. New Phytol. 89:495-502.

Marshall, C. 1990. Source-sink relations of interconnected ramets, p. 23-41. In: J. van Groenendael and H. de Kroon (eds.). Clonal growth in plants: Regulation and function. SPB Academic Publishing, The Hague, The Netherlands.

Marshall, C. and E.A.C. Price. 1999. Clonal plants and environmental heterogeneity: Space, time and scale. Plant Ecol. 141:1.

Minner, D.D., J.H. Dunn, S.S. Bughrara, and B.F. Fresenburg. 1997. Effect of topdressing with "Profile" porous ceramic clay on putting green quality, incidence of dry spot and hydraulic conductivity. Intl. Turfgrass Soc. Res. J. 8:1240-1249.

Nayyar, N. 2003. Variation in osmoregulation in differentially drought-sensitive wheat genotypes involves calcium. Biol. Plant. 47:541-547.

Nyahoza, F., C. Marshall, and G.R. Sagar. 1974. Assimilate distribution in Poa pratensis L.: A quantitative study. Weed Res. 14: 251-256.

Pitelka, L.F. and J.W. Ashmun. 1985. Physiology and integration of ramets in clonal plants, p. 399-435. In: J.B.G. Jackson, L.W. Buss, and R.E. Cook (eds.). The population biology and evolution of clonal organisms. Yale University Press, New Haven, CT.
Pozarnsky, T. 1983. Buffalograss: Home on the range, but also a turf grass. Rangelands 5:214-216.

Qian, Y., D. Li, L. Han, G. Ju, J. Liu, J. Wu, and Z. Sunday. 2009. Interramet physiological integration detected in buffalograss (Buchloe dactyloides (Nutt.) Engelm.) under water stress. Korean J. Turfgrass Sci. 23:331-343.

Ryle, G.J.A., C.E. Powell, and A.J. Gordon. 1981. Patterns of 14-Clabelled assimilate partitioning in red and white clover during vegetative growth. Ann. Bot. (Lond.) 47:505-514.

Salisbury, F.B. and C.W. Ross. 1992. Plant physiology. 4th ed. Wadsworth, Belmont, CA.

St. Pierre, J.C. and M.J. Wright. 1972. Distribution of 14-C photosynthates in timothy (Phleum pratense L.) during vegetative growth. Crop Sci. 12:191-194.

Stuefer, J.F., H.J. During, and H. de Kroon. 1994. High benefits of clonal integration in two stoloniferous species, in response to heterogeneous light environments. J. Ecol. 82:511-518.

Taliaferro, C.M. and P. McMaugh. 1993. Developments in warm-season turfgrass breeding/genetics. Intl. Turfgrass Soc. Res. J. 7:14-25.

Tanino, K., C.J. Weiser, L.H. Fuchigami, and T.T.H. Chen. 1990. Water content during abscisic acid induced freezing tolerance in bromegrass cells. Plant Physiol. 93:460-464.

Warren, J.M., J.R. Brooks, F.C. Meinzer, and J.L. Eberhart. 2008. Hydraulic redistribution of water from Pinus ponderosa trees to seedlings: Evidence for an ectomycorrhizal pathway. New Phytol. 178:382-394.

Weiler, E.W., P.S. Jordan, and W. Conrad. 1981. Levels of indol-3acetic acid in intact and decapitated coleoptiles as determined by a specific and highly sensitive solid-phase enzyme immunoassay. Planta 153:561-567.

Yang, J., J. Zhang, Z. Wang, Q. Zhu, and W. Wang. 2001. Hormonal changes in the grains of rice subjected to water stress during grain filling. Plant Physiol. 127:315-323.

Zhang, J. and W.J. Davies. 1989. Abscisic acid produced in dehydrating roots may enable the plant to measure the water status of the soil. Plant Cell Environ. 12:73-81.

Zhang, X. and R.E. Schmidt. 1999. Antioxidant response to hormonecontaining product in kentucky bluegrass subjected to drought. Crop Sci. 39:545-551. 